\title{
Does Gender in Children's Books Matter?
}

\author{
Maya Lestari ${ }^{1, *}$, Hani Yulindrasari ${ }^{2}$ \\ ${ }^{1,2}$ School of Postgraduate Studies, Universitas Pendidikan Indonesia, Bandung, Indonesia \\ *Corresponding author. Email: mayalestari@upi.edu
}

\begin{abstract}
This paper analysed gender representations in children's books. To be specific, the paper assesses gender equality in children's books. In general, children acquired gender concepts from the culture within the society. Then, it is transmitted through various media, book is one of them. Gender is defined as a characteristic of men and women constructed by society and culture. As one of cultural products, books convey cultural messages including gender messages. Children's books contain narratives and pictures of men and women and messages about contemporary men and women. Based on literature research this paper argues that children's books contribute to shaping children's understanding about society and themselves. This paper is organized as follows, first, the concept of gender will be explained. Second, the paper will combine several previous studies on various issues and how children's books constructed the concept of gender for children. Third, the paper analyses the importance of gender equality in children's books. The paper concludes that children's books play an important role in shaping children's understanding about gender equality.
\end{abstract}

Keywords: Gender, media, children's book.

\section{INTRODUCTION}

Books are an important medium in shaping people's understanding about the world. Over the centuries, children have learned their role in society through books. Gender messages are one of the cultural messages conveyed through books. Representations of women and men in the media provide ideas about gender that could be transferred to the audience [1], [2]. Therefore, it is possible that gender representation in children's books will shape children's understanding about gender roles. However, the media are unlikely to have a direct effect on their audience at the same time. We should not arbitrarily assume that children are copying or borrowing their full understanding of gender from the media they use.

Furthermore, children who live in a different era. Therefore, what children learn about gender from books in the 1990s may not be relevant with children's context today. Gender changes overtimes, and so do ideas in books. Ideas about gender in contemporary society has become more complex. The complexity can be identified through how the media, including books, represents the role and social attribution of men and women.

The history of children's books development began in the mid-18th century [3]. At that time, discourse in children's books represented popular culture. The relationship between children and children's books today is like an electronic communication medium with the audiences. Children interact with books in two ways: children as readers and children as spectators or observers [4], [5]. In addition, the interaction of children and books can also be identified from other early literacy practices such as storytelling to children [6].

In most societies, storytelling is one of the most important ways to disseminate the norms, values, and cultural attitudes to children. Therefore, children's books are used as a medium for social learning and identity development. Children's books also give children some of their initial perceptions about gender, race, and class. Children's perceptions about their position and role in society as girls and boys will be shaped through children's interactions with books.

This paper discusses previous research on gender in children's books to show how children's books have become a medium for (re)construct and (re)negotiate children's understanding of gender. The paper argues that gender is an important medium to instil equal and egalitarian understanding of gender.

\section{WHAT IS GENDER?}

Discussing the concept of gender, it is necessary to distinguish between gender and sex. Sex is a human biological characteristic inherent in a certain sex [7], [8]. For example having and producing sperm for men and having a uterus and vagina, and producing eggs for women. These characteristics are permanent and carried 
over from birth so that they become biological provision or are often referred to as (fitrah) nature or desires from God.

On the other hand, gender is something that is inherent in both women and men which is built from society and culture. In addition, these gender traits are interchangeable [9], [10]. This is because the changes can be made from uncertain times, from one place to another. The emergence of gender differences can also be influenced by many things since they formed, promoted, perpetuated, and taught in a social, cultural, religious and national context.

This includes the construction of ideas that men should be strong and aggressive, while women tend to be gentle. The results of this construction in the community, which are then normalized, are often considered contradictory if the gender is exchanged. This normalized gender difference is used as a way of providing opportunities for the emergence of gender inequality in various aspects, including the media.

\subsection{Women and Men Today}

Before further discussing the role of children's books as mediums, we intend to provide an overview of the relative democratic of women and men in Indonesia. In general, both men and women have the same rights in democracy. Gender equality has been echoed globally and has become one of the global developmental goals, which are now known as the Sustainable Development Goals [11].

Gender equality is still an effort that must be fought for together. Gender inequality always occurs in various aspects of Indonesia Today For example, work is still gendered. Indonesian leaders are more dominated by men. Some sectors of work normalize the dominance of men over women and separate other jobs specifically because the majority are done by women. For example, 6 out of 7 Indonesian presidents are men. Jobs such as pilot, engineering, and journalism are mostly done by men. On the other hand, care related work is included as women's [12].

Furthermore, although the traditional view of women as dedicated 'housewives', such as women having to stay at home and men having to work, have almost disappeared in today's society, more people are expressing freedom of choices, including how they live. Being a housewife or a career woman is the choice of every individual. When deciding to have a career outside the house, many women actually have double responsibility (as housewives and as career women outside the house).

\subsection{The Urgency of Gender Equality in Children's Books}

Reading is an activity that can enrich children's experiences and knowledge. During the reading activity, children became keen observers in observing stories and pictures in books [4], [13]. This indicates that books are an important resource for children. Children's books transmit values, culture, and social life in society. Children's books are also part of the early media that children often play in their daily lives. So that children's books contribute to shaping concepts about something [3], [14], [15].

The concept of gender, as stated earlier, is an inherent trait for both men and women. The idea of gender is constructed by society and culture According to various studies, knowledge about the concept of gender is usually obtained through direct or indirect interactions. For example, in early childhood education settings, knowledge of gender concepts can be influenced by the teachers' perceptions in classroom [16], [17], interactions with peers during play activities [18]-[21], and through the media used by children. Media used by the children can be in the form of electronic media or printed media [1], [2], [22].

There is a widely held belief that books are windows to the world. A lot of information can be obtained by children from books either read directly or in the form of storytelling [15], [23]. This is one of the reasons why children's books have become part of printed media that also give colour to children's knowledge. This belief will provide a perception for children to achieve broader skills and opportunities for academic achievements and employment, and to act in the society with equal access.

Children's books help children understand the concept of gender. So that the discourse on gender equality must be a common concern. Based on the literature review, children's books still show gender bias. For example, more depicting men than women and using traditional gender roles to portray male and female characters in children's books [14], [15], [24]

Exploring gender bias in children's books is deemed necessary because children's books are a medium for gaining knowledge. As one of the media used by children in everyday life, children's books provide various interpretations for children as readers. Children's books are also literary works that can promote and build children's knowledge about gender through discourse and pictures, in the context of fictional storybooks, which contain fairy tales and non-fiction thematic books such as classroom learning activity books. Pictures and illustrations of stories in books have a large space in children's books [25]. Therefore, children will think about gender and see mothers, fathers, daughters, and sons' roles. Also, find out what activities boys and girls can do through children's books. 
Therefore, more studies on gender representation in children's books need to be carried out. Because from an early age, children begin to understand gender and gender stereotypes apply to themselves. So that we can also naturally ask what types of books teach children about gender [14].

The diversity of characters in children's books is important. Because children need to see what kind of characters they represent in the media. So that children do not feel isolated [26]. When children do not see themselves represented in the books, it can affect their self-esteem.

The urgency of gender equality in children's books is part of the responsibility of adults, at home and in educational settings, to provide quality learning resources for children. To achieve this, adults (teachers, parents, communities, and other adults) must be aware of gender representation and reflect the content of children's books with the concept of gender equality.

\section{CONCLUSION}

Based on the result of the literature review, it can be concluded that the media had contributed in shaping the concept of gender in society. However, the media often created stereotypes about the characters depicted in books especially in children's books which are the focus of this study. Children's books are a useful medium for early childhood education, both at school and at home. In addition, children's books have the potential to influence children's initial understanding of the concept of gender. Therefore, the representation of gender equality in children's books needs to be discussed further.

There are various children's books, some of which tell stories of fiction and non-fiction. Both fiction and nonfiction stories illustrate how to represent narrative discourse and visualization, and female and male characters related to gender in children's books. Researchers further suggested discourse analyses related to gender representation in children's books in kindergarten.

\section{REFERENCES}

[1] Wohlwend KE. 'Are you guys girls?': Boys, identity texts, and Disney princess play. Journal of Early Childhood Literacy. 2012;12(1):3-23.

[2] Gauntlett D. Media, gender and identity: An introduction. London: Routledge; 2008.

[3] Sunderland J. Language, gender and children's fiction. Bloomsbury Publishing; 2010. Available from:https://books.google.com/books?id=Vf9GAQ AAQBAJ\&pgis=1.

[4] Chen S. Reading visual narratives: image analysis of children's picture books. Social Semiotics.
2014;24(5):623-27. Available from: https://doi.org/ 10.1080/10350330.2014.950010.

[5] Gilkerson J, Richards JA, Topping KJ. The impact of book reading in the early years on parent-child language interaction. Journal of Early Childhood Literacy. 2017;17(1):92-110.

[6] Isbell R, Sobol J, Lindauer L, Lowrance A. The effects of storytelling and story reading on the oral language complexity and story comprehension of young children. Early childhood education journal. 2004;32(3):157-63.

[7] McGeown SP. Sex or gender identity? Understanding children's reading choices and motivation. Journal of Research in Reading. 2015;38(1):35-46.

[8] Maccoby EE. Perspectives on gender development. International Journal of Behavioral Development. 2000;24(4):398-406.

[9] Meland AT, Kaltvedt EH. Tracking gender in kindergarten. Early Child Development and Care. 2019;189(1):94-103.

[10]Kabeer N. Gender equality and women's empowerment: A critical analysis of the third millennium development goal 1. Gender \& Development. 2005;13(1):13-24.

[11]Perempuan KP, Anak P, Statistik BP. Pembangunan manusia berbasis gender. Jakarta: Kementerian Pemberdayaan Perempuan dan Perlindungan Anak; 2018.

[12] Yulindrasari H, McGregor K. Contemporary discourses of motherhood and fatherhood in Ayahbunda, a middle-class Indonesian parenting magazine. Marriage \& Family Review. 2011;47(8):605-24. Available from: https://doi.org/ 10.1080/01494929.2011.619304.

[13]Endendijk JJ, Groeneveld MG, Van der Pol LD, Van Berkel SR, Hallers-Haalboom ET, Mesman J, Bakermans-Kranenburg MJ. Boys don't play with dolls: Mothers' and fathers' gender talk during picture book reading. Parenting. 2014;14(3-4):14161. Available from: https://doi.org/10.1 080/15295192.2014.972753.

[14]Filipović K. Gender representation in children's books: Case of an early childhood setting. Journal of Research in Childhood Education. 2018;32(3):31025. Available from: https://doi.org/10.1 080/02568543.2018.1464086.

[15] Sari RD, Moecharam NY, Hermawan B, Riesky MP. Perspektif gender anak usia dini melalui reproduksi narasi buku cerita anak berarketip gender. JPUD: Jurnal Pendidikan Usia Dini. 2010;13(1):1-15.

[16] Warin J, Adriany V. Gender flexible pedagogy in early childhood education. Journal of Gender 
Studies. 2017;26(4):375-86. Available from: https://doi.org/10.1080/09589236.2015.1105738.

[17] Adriany V, Warin J. Preschool teachers' approaches to care and gender differences within a child-centred pedagogy: Findings from an Indonesian kindergarten. International Journal of Early Years Education. 2014;22(3):315-28. Available from: https://doi.org/10.1080/09669760.2014.951601.

[18]Lynch M. Guys and dolls: A qualitative study of teachers' views of gendered play in kindergarten. Early Child Development and Care. 2015;185(5):679-93. Available from: https://doi. org/10.1080/03004430.2014.950260.

[19] Adriany V. Being a princess: young children's negotiation of femininities in a Kindergarten classroom in Indonesia. Gender and Education. 2019;31(6):724-41. Available from: https://doi. org/10.1080/09540253.2018.1496229.

[20] Adriany V. 'I don't want to play with the Barbie boy': Understanding Gender-Based Bullying in a Kindergarten in Indonesia. International journal of bullying prevention. 2019;1(4):246-54. Available from:https://link.springer.com/article/10.1007/s423 80-019-00046-2.

[21]Lestari M. Bagaimana Konstruksi Gender dalam Permainan Outdoor di PAUD?. PERNIK: Jurnal Pendidikan Anak Usia Dini. 2020;3(2):1-9 Available from: http://dx.doi.org/10.31851/ pernik.v3i2.4810.

[22] Ttuglio RT, Kotler JA, Cohen DI, Housley- Juster A. Modelling life skills on Sesame street. Televizion [Internet]. 2005;(18):15-9. Available from: https://www.bronline.de/jugend/izi/english/publicat ion/televizion/18_2005_E/truglio.pdf.

[23] Napoli AR, Purpura DJ. The home literacy and numeracy environment in preschool: Cross-domain relations of parent-child practices and child outcomes. Journal of Experimental Child Psychology. 2018;166:581-603. Available from: https://doi.org/10.1016/j.jecp.2017.10.002.

[24] Sovič A, Hus V. Gender stereotype analysis of the textbooks for young learners. Procedia-Social and Behavioral Sciences. 2015;186:495-501. Available from: https://doi.org/10.1016/j.sbspro.2015.04.080.

[25] Yang CC. Are males and females still portrayed stereotypically? Visual analyses of gender in two Hong Kong primary English language textbook series. Gender and Education. 2016;28(5):674-92.

[26] Wingrave M. Perceptions of gender in early years. Gender and Education. 2018;30(5):587-606. 